\title{
Kuntien johtoryhmien kertomuksia työuupumuksesta
}

\author{
Annemaija Summanen, Teppo Sintonen \& Tuomo Takala
}

\section{ABSTRACT \\ Burnout Narratives of Municipal Management Teams.}

This study aims to gain an understanding of personal experiences of burnout phenomenon among members of municipal management teams. Fourteen managers were interviewed. Four types of burnout narratives were identified: denier, persevering, recovered and defender. These data were analysed using Labov \& Walezky's model of the structural types of narrative clauses. The analysis reveals similarities and differences of burnout experiences within each of the identified narrative types. Particularly, the study explores the role of workplace community in burnout recovery.

Keywords: Burnout, narrative methods, municipal management

\section{JOHDANTO}

Tässä tutkimuksessa tarkastelemme suomalaisten kuntien johtoryhmien jäsenten kokemuksia ja käsityksiä työuupumuksesta. Työuupumus on noussut viime aikoina merkittäväksi negatiiviseksi tekijäksi työelämässä, johtuen muun muassa vaativista tulostavoitteista, lisääntyneistä yt-neuvotteluista, toistuvista organisaatiomuutoksista ja yleisemmästä työn muutoksesta (Kinnunen \& Hätinen 2005, Rikala 2013). Omat paineensa kunta-alan johtajien työhön toi tämän tutkimuksen aineistonkeruun aikana valmisteilla ollut suuri sote- ja maakuntauudistus (jonka valmistelu tosin lopetettiin 2019). Vaikka johtoryhmän jäsenet toivovat jaksavansa työssään uupumatta, ei ilmiöstä eikä omasta jaksamisesta johtamistyössä kovin usein puhuta ääneen. Vaikenemisella taas on merkitystä johtajan työhyvinvointiin.
Pitkäkestoinen stressi johtamistyössä voi pahimmillaan johtaa työuupumukseen. Työuupumuksen määritelmistä tunnetuin ja tässä artikkelissa käytetty on Maslachin ja Leiterin (1997) tekemä määritelmä, jonka mukaan työuupumus on kolmitahoinen oireyhtymä. Sillä on kolme ominaista tekijää: uupumusasteinen väsymys, kyynistynyt asenne työhön (työyhteisöön) ja ammatillisen itsetunnon heikkeneminen. Työuupumuksessa on laajemmin kyse myös työelämään liittyvästä ajanhallinnasta ja työn muutoksesta, mikä tekee siitä merkittävän yhteiskunnallisen kysymyksen (Widerberg 2006).

Toteutimme tutkimuksemme kertomuksellisella eli narratiivisella tutkimusotteella ja tarkastelumme perustana oli Leiterin ja Maslachin (1988) ajatukset työuupumuksen kehittymisestä sekä Kalimon ja Toppisen (1997) kehittämä työuupumuksen prosessimalli yhdistettynä kertomukselliseen/narratiiviseen prosessianalyysiin. Narratiivisen analyysin toteutimme Labovin ja Waletzkyn (1997) kertomuksen rakenneosamallin kautta. Tutkimuksemme keskiössä on johtoryhmän jäsenten työuupumusta koskevista kertomuksista löytyvät neljä kertomustyyppiä: kiistäjäkertomukset, sinnittelijäkertomukset, selviytyjäkertomukset ja puolustajakertomukset. Näiden tyyppien yhtäläisyyksiä ja eroja analysoimalla voidaan tarkentaa käsitystä työuupumuksesta.

Tarkastelimme johtoryhmän jäsenten työuupumuskertomuksia suomalaisessa kuntakontekstissa. Neljäntoista tutkimukseen osallistuneen johtoryhmän jäsenen kertomukset muodostavat harvinaislaatuisen ja monipuolisen aineiston, jonka kautta työuupumusta voidaan tarkastella lähietäisyydeltä ja eletyn elämän kokemusten kautta. Vaikka aivan kaikki haastatellut eivät olleetkaan itse kokeneet varsinaista työuupumusta, he olivat kokeneet jonkinasteista väsymystä tai stressiä sekä seuranneet uupumustapauksia työyhteisöissään. Siten heille on kertynyt omakohtaista kokemusta ja tietämystä 
työuupumuksesta. Tutkimuksemme anti onkin juuri osallistujien henkilökohtaisten kokemusten esiintuomisessa. Työuupumuskertomukset antavat uutta ja täydentävää tietoa ilmiöstä perinteisen määrällisen kyselytutkimuksen rinnalle (ks. Kinnunen ja Hätinen 2005; Hakanen 2005). Lisäksi tutkimuksemme on eräänlainen pilottitutkimus, mitä tulee työuupumuksen tutkimiseen narratiivisella menetelmällä.

Johtoryhmän jäsenen työuupumuksen oireiden varhainen tunnistaminen on tärkeää yhteiskunnallisella, organisaatio ja yksilötasoilla. Laajassa mielessä työuupumus on koko yhteiskuntaa ja työelämää koskeva ongelma, joka vaikuttaa työn organisointiin niin julkisella kuin yksityisellä sektorilla. Organisaatiotasolla kyse on organisaatioiden sisäisestä työkulttuurista, joka ei anna henkilöstölle mahdollisuutta selviytyä työtehtävistä (Rikala 2013). Lisäksi voimakkaasti uupunut esimies heijastaa herkästi omaa pahoinvointiaan vastuualueelleen ja näin työuupumus voi siirtyä organisaatiossa toisille henkilöille. (ks. esim. Tarkkonen 2012; Hakanen ja Perhoniemi 2012; Frantsi 2013). Yksilötasolla työuupumus ilmenee toimintakyvyn heikkenemisenä ja moninaisina psyko-sosiaalisina ongelmina. Kaikkiaan työuupumuksen tunnistaminen edellyttää tietoa sen syntymiseen ja kehittymiseen johtavista tekijöistä ja tästä syystä tässä tutkimuksessa tarkastellaan työuupumusta prosessina.

\section{TUTKIMUSKOHTEENA TYÖUUPUMUS}

Työuupumuksen tutkimus on alkanut varsinaisesti 1970-luvulla (Freudenberger 1974; Maslach 1976). Työuupumus ei sinänsä ole uusi ilmiö ja sen oireistoa on tutkittu mm. väsymyksen, työhön liittyvän intohimon katoamisen ja burnoutin kaltaisten käsitteiden kautta jo aiemmin. (Schaufeli ja Enzmann 1998; Vartiovaara 1996). Riippumatta käytetyistä käsitteistä, työuupumuksen on kuvattu ilmenevän jaksamattomuuden tuntemuksina, puuttuvana motivaationa, negatiivisena suhtautumisena omaan itseen, toisiin ihmisiin ja työhön sekä vetäytymisenä vuorovaikutuksesta (Maslach 1982).

Suomessa työntekijöiden rasitustekijöitä on tutkittu systemaattisesti 1970-luvulta saakka. Tilastokeskus on vuodesta 1977 alkaen toteuttanut laajoja työolotutkimuksia ja Työ- ja elinkeino- ministeriö on laatinut vuosittaisia työolobarometrejä vuodesta 1992 alkaen. Barometrien keskeisiä sisältöjä ovat mm. työn organisointi, työaika- ja palkkausjärjestelmät, vaikutusmahdollisuudet työhön, syrjintä ja kiusaaminen työpaikoilla sekä työkyky ja terveys. Tämän tutkimuksen kannalta oleellinen barometrien esiintuoma asia on, että kunta-alalla työ koetaan usein henkisesti kuormittavana. Esimerkiksi vuoden 2012 Kunta-alan työolobarometrin mukaan jopa 76 prosenttia työntekijöistä kokee työnsä henkisesti raskaaksi. Kuntajohtajiin paineet kohdistuvat muun muassa siksi, että meneillään ollut kunta- ja palvelurakenneuudistus paineisti kuntien henkilöstöjohtamista. (Viitala ja Lehto 2014, 134-135.)

Tutkimuksellinen kiinnostus työuupumukseen liittyy vahvasti yhteiskunnan ja työelämän muutoksiin. Suomessa tutkimuksen tarve lisääntyi erityisesti 1990-luvun laman aiheuttamana. Taloudellinen lama ja sitä seurannut työpaikkojen menetys tai menettämisen pelko sekä työolojen kiristyminen nostivat esiin työssäjaksamisen ongelmat. Erilaiset väsymysoireet, unettomuus, työpaineet, kokemus oman työn hallitsemattomuudesta ja stressitekijät lisäsivät työuupumustapauksia, mikä teki uupumuksesta merkittävän yhteiskunnallisen ongelman. Työuupumus aiheutti myös uupumuskierteen työpaikoilla, koska yhden työntekijän työkyvyttömyys lisäsi muiden työntekijöiden työtaakkaa. (Kalimo ja Toppinen 1997; Otala ja Ahonen 2003)

Työuupumusta on tutkimuksellisesti lähestytty monenlaisista näkökulmista eikä sille välttämättä ole yhtä kaikkien hyväksymää määritelmää (Kinnunen ja Hätinen 2005). Yleisimmin työuupumus kytketään työstä aiheutuvaan stressiin. Sitä voidaan pitää suhteellisen vaikea-asteisena psyykkisenä häiriötilana (Vartiovaara 1987), voimakkaana psykologisena kuormittuneisuutena, joka johtuu energiavarojen loppumisesta stressitekijöiden vallitessa (Kinnunen ja Hätinen 2005) tai selviytymiskeinojen ehtymisestä johtuvana työväsymystä vakavampana oireyhtymänä (Hakanen 2005). Työuupumus ei ilmiönä ole yksiulotteinen, vaan se kiinnittyy kaikkiin työelämän negatiivisiin elementteihin, kuten kiireeseen, työn epävarmuuteen huonoon johtamiseen ja työn organisointiin, työpaikan epäluottamukseen sekä epäoikeudenmukaisuuteen (Kalimo ja Toppinen 1997). 
Työuupumus on myös psykologinen prosessiilmiö. Se syntyy pitkittyneestä työperäisestä stressistä ja johtaa niin fyysiseen kuin henkiseenkin väsymystilaan. Siten työuupumuksen ensimmäisenä asteena on usein uupumustyyppinen väsymys (Maslach ym. 2001), josta kehkeytyy sen pahetessa kyynistyminen ja heikentynyt ammatillinen itsetunto (Ahola 2007; Hakanen 2005; Schaufeli ja Enzmann 1998). On kuitenkin huomattava, että työuupumusta ei luokitella sairaudeksi eikä sen vuoksi voi saada esimerkiksi sairauslomaa. Sen sijaan työuupumustapauksissa sairauslomadiagnoosi on yleensä masennus. Tässä piilee yhteiskuntapoliittinen ongelma koska työuupumuksesta toipumiseen tarvittava sairausloma legitimoidaan masennusdiagnoosilla, joka taas on monelle uupuneelle vieras käsitys omasta tilasta ja osalle heistä jopa häpeällinen tilanne. (Rikala 2013.) Tässä tutki- muksessa lähestymme työuupumusta nimenomaan prosessina eli olemme kiinnostuneita sen alkuun liittyvistä tekijöistä, miten se kunkin kokijan kohdalla etenee ja miten siitä voi selvitä.

Työuupumuksen kehittymistä on kuvattu useilla erilaisilla malleilla, joille on yhteistä yksilön ja hänen ympäristönsä vuorovaikutus. Erilaiset ulkoiset tekijät vaikuttavat yksilöön siten, että häneen alkaa kasaantua negatiivista painolastia. Tämä painolasti ilmenee esimerkiksi emotionaalisena uupumuksena, asennemuutoksina, kokemuksena omien voimavarojen vähenemisestä ja ammatillisen itsetunnon heikkenemisenä. (Schaufeli ja Bakker 2004; Golembiewski ja Münzenrider 1988; Leitner ja Maslach 1988). Kalimo ja Toppinen $(1997,14)$ ovat kuvanneet työuupumukseen vaikuttavia tekijöitä ja sen etenemistä alla olevan mallin mukaisesti.

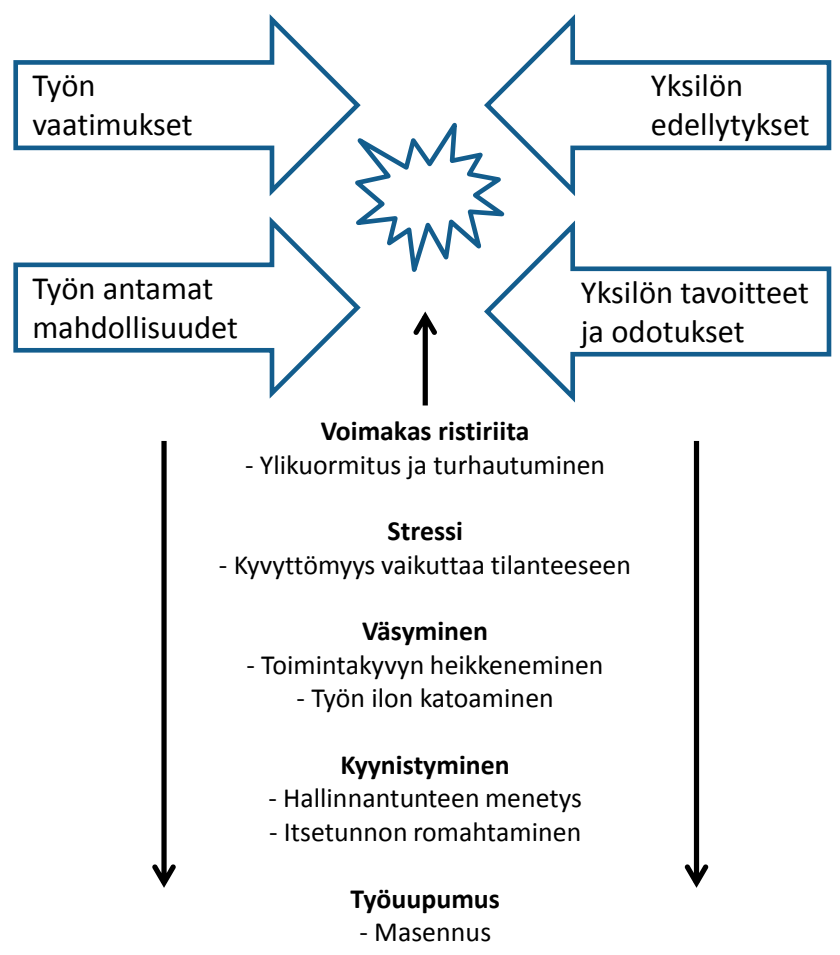

Malli 1. Työuupumuksen kehitys (Kalimo ja Toppinen 1997, 14) 
Työuupumukseen johtavat vaiheet lähtevät liikkeelle yksilön ja työtehtävien välisestä jännitteestä. Ristiriitatilanne syntyy, kun työn asettamat vaatimukset ja mahdollisuudet kohtaavat epäsymmetrisesti yksilön edellytykset sekä tavoitteet ja odotukset. Tästä ristiriidasta voi yksilölle kehittyä stressiä, jossa työn ylikuormittuneisuudesta johtuen omat vaikutusmahdollisuudet työtehtäviin koetaan heikkoina tai jopa olemattomina. Jos stressi ei katoa työpaineiden hellitettyä, siitä voi kehittyä kyyninen asennoituminen työhön ja kanssaihmisiin. Kyynisyys ilmenee yleensä asioiden merkitysten vähättelynä, välinpitämättömyytenä ja jopa pilkallisuutena toisten ihmisten tekemisiä kohtaan. Viimeisenä vaiheena on työuupumus, joka ilmenee masentuneisuutena. Keskeinen ero stressin ja työuupumuksen välillä on, että yksilö yleensä toipuu stressistä ilman mitään erityisiä toimenpiteitä, kun kuormitusta aiheuttanut haastava työtehtävä poistuu tai tulee hoidetuksi (Hakanen 2005; Maslach ym. 2001; Kalimo ja Toppinen 1997).

\section{AINEISTO JA MENETELMÄ}

Tutkimuksemme aineisto koostuu neljästätoista kunta-alan johtoryhmän jäsenen haastattelusta. Valitsimme haastateltavat ylemmistä viranhaltijoista, jotka toimivat eri kunnallisten toimialojen johtajina tai johtavassa asemassa. Heidän valintakriteerinään ei toiminut omakohtainen työuupumuskokemus vaan halusimme ottaa tutkimukseen kaikkien tutkimuskohteeksi valittujen kuntien johtoryhmien jäsenet. Näin pyrimme kattavaan otokseen tietyltä maantieteelliseltä alueelta. Osa tutkituista ei ollut kokenut työuupumusta itse, mutta he olivat seuranneet kollegoidensa ja alaistensa uupumustapauksia hyvin läheltä. Siten heillekin oli kertynyt tietoa ja ymmärrystä johtoryhmätason työuupumuksesta. Omakohtainen työuupumus tai sen kokemattomuus heijastui myös kertomustyyppien muotoutumiseen. Sinnittelijä- ja selviytyjäkertomukset kuvaavat jo itsessään omakohtaista työuupumuskokemusta: sen kanssa on sinniteltävä tai siitä voi myös selviytyä. Kiistäjäkertomuksissa oman kokemuksen määrittäminen on epäselvää, koska nämä kertojat eivät pitäneet uupumusta työperäisenä eivätkä siten voineet määrittää omia oireitaan nimenomaan työuupumukseksi. Puolustajakertomuksissa työuupumusta oli seurattu lähietäisyydeltä omassa työyhteisössä kuitenkin ilman omakohtaista työuupumusta. Merkittävää tässä kertomustyypissä oli, että työuupumukseen suhtauduttiin todellisena ilmiönä. Omakohtainen työuupumuksen kokeminen ei siten ollut tutkimuksessa määräävä kriteeri aineistolle. Oleellista oli oman aseman kautta kertynyt tietämys ja kokemus kyseisestä ilmiöstä niin yksilöllisenä kuin yhteisöllisenä ongelmana.

Lähetimme tutkittaville ensin haastattelupyynnön sähköpostitse ja tämän jälkeen tarkensimme vielä puhelimitse haastattelun ajankohtaa. Sähköpostissa annettiin yleinen kuvaus tutkimuksen tavoitteesta eli työuupumuskokemusten keräämisestä sekä painotettiin tutkimuksen luottamuksellisuutta ja haastateltavien anonymisointia. Jokaiselta tutkimukseen suostuneelta pyydettiin vielä kirjallinen suostumus, jossa haastattelupyynnön tietojen lisäksi kerrottiin aineiston turvallisesta säilyttämisestä. Lähetimme haastattelupyyntöjä kaikkiaan seitsemälletoista johtoryhmän jäsenelle, joista yksi kieltäytyi jo aluksi ja kaksi vetäytyi tutkimuksesta haastattelun jälkeen. Tutkimuseettisesti kieltäytymisen ja vetäytymisten syistä voidaan kertoa vain sen verran, että ne perustuivat haluttomuuteen muistella omakohtaisia vaikeita kokemuksia. Haastatteluja tehtiin siis kuusitoista ja lopulliseen tutkimukseen osallistui neljätoista johtoryhmän jäsentä. Heistä naisia oli kuusi ja miehiä kahdeksan. Tutkittavien iät vaihtelivat 38-vuotiaasta 62-vuotiaaseen. Yhtä lukuun ottamatta kaikilla oli vähintään alempi korkeakoulututkinto, joskin tutkintojen alat vaihtelivat laajalti.

Toteutimme haastattelut teemahaastatteluina ja ne kestivät reilusta tunnista vajaaseen kahteen tuntiin. Yhteensä haastattelut kestivät kaksikymmentä tuntia viisikymmentä seitsemän minuuttia. Litteroitua aineistoa kertyi noin 320 sivua. Haastattelut etenivät siten, että aluksi kerättiin kontekstitietoja käymällä läpi haastateltavan työhistoriaa ja kunta-alalla johtajana toimimista. Johtamisen kohdalla keskusteltiin johtamisen haasteista sekä johtamisen ja työuupumukset kytköksistä. Seuraavaksi siirryttiin haastattelun pääteemaan eli työuupumukseen. Työuupumuksen teemoina olivat haastateltavan omat tiedot ja käsitykset työuupumuksesta, omakohtaiset työuupumuskokemukset ja selviytymiskeinot, huomiot kollegojen työuupumuksesta sekä työyhteisöjen merkitykseen työuupumuksesta 
selviytymisessä. Työuupumuksen prosessiluonteesta saatiin tietoa kysymällä haastateltavilta ovatko he itse kokeneet työuupumuksen ja jos ovat, niin mikä sen aiheutti, miten se eteni ja miten he siitä selviytyivät. Haastateltavia pyydettiin kertomaan myös havaintojaan työyhteisössään olleista työuupumustapauksista sekä yhteisön sosiaalisen tuen merkityksestä näissä tapauksissa. Lopuksi haastateltavalla oli vapaa sana tehdä lisäyksiä ja tarkennuksia.

Valitsimme tutkimukseemme kertomuksellisen eli narratiivisen menetelmän kahdesta syystä. Ensinnä, tutkimuskohteena työuupumus on ihmisen arkikokemukseen hyvin läheisesti liittyvä ilmiö joka koskettaa ihmistä yksilöllisesti hänen omissa ja luonnollisissa ympäristöissään. Työuupumus ei siten merkitse kaikille sen kokeneille samaa asiaa, vaan se koetaan ja siitä selviydytään eritavoin. Tämän vuoksi emme päätyneet määrälliseen ja työuupumuksen eri osa-alueita mittaavaan tutkimustapaan. Narratiivinen tutkimusote soveltuu työuupumuksen tutkimiseen siksi, että jo lähtökohtaisesti ihmiset ymmärtävät ja merkityksellistävät elämäänsä ja kokemuksiaan kertomusten kautta ja avulla (ks. Bruner 1986; Polkinghorne 1995; Sintonen 1999). Tarkastelemme siten työuupumusta johtamiskontekstissa kertomuksellisesta maailmasta käsin ja keskiössä on tutkittavien henkilöiden omakohtaiset kokemukset.

Toinen syy narratiivisen tutkimusotteen käyttöön liittyy työuupumuksen prosessiluonteeseen. Työuupumus alkaa jostakin ajankohdasta, kestää tapauskohtaisesti oman aikansa ja todennäköisesti loppuu jonakin ajankohtana. Tähän väliin sijoittuu monimuotoisia tapahtumia ja erilaisten toimijoiden enemmän tai vähemmän aktiivisia toimia. Nämä tapahtumat ja toimet jäsentyvät ajallisesti ja tulevat ilmaistuiksi kertomusten muodossa. Kertomuksissa ajallisuus ja sen prosessiluonne ilmenevät sekä kertomuksen sisältämien tapahtumien keskinäisinä suhteina, että kertomuksen sisäisen ajallisuuden kautta (Boje 2008; Hyvärinen 2006). Kertomuksen tapahtumat muodostavat ajallisen ulottuvuuden siten, että jokin tapahtuma kerrotaan toista tapahtumaan ennen tai sen jälkeen. Näin kerrottujen tapahtumien keskinäinen jäsennys tuottaa kertomukseen ajallisen ulottuvuuden. Kertomuksen sisäinen ajallisuus taas tulee esiin kertojan esittämien asioiden ajallisuuden kautta.
Kertoja voi viitata kerronnassaan tapahtumiin jotka ovat tapahtuneet menneisyydessä tai tulevat mahdollisesti tapahtumaan tulevaisuudessa. Tällöin hän esimerkiksi pohtii jotakin mennyttä tapahtumaa tai luo mielikuvia tulevaisuudestaan. Kertoja voi siten luoda kertomukseensa ajallisen jäsennyksen, joka ei ole riippuvainen kerronnan jäsennyksestä.

Halusimme tutkia työuupumusta osana johtavassa asemassa olevien henkilöiden työn arkea. Kohteena olivat tavat, joilla tutkittavat kertovat työuupumuksesta. Narratiivinen menetelmä kielenkäytön tutkimuksena rajaa pois esimerkiksi tunnetilojen fyysiset ulottuvuudet, mutta keskittyy siihen, miten tutkittavat kielellistävät ja kertomuksellistavat kokemuksensa. Viimekädessä tutkimuksessa analysoidaan siis työuupumuksen kertomuksellisia representaatioita.

Varsinaisen aineiston, johtoryhmien jäsenten kertomusten, analysointiin käytimme Labovin ja Waletzkyn (1997 [1967]) kertomuksen rakennemallia. Mallin anti analyysille oli nimenomaan siinä, että se sisältää kertomuksen kulkuun ja sen kertojan tai toimijan tarkoitusperiin liittyvät elementit. Lisäksi malli tuo esiin mikä kertomuksessa oli hyvää, pahaa, merkittävää, arvostettavaa tai erityistä (Hyvärinen 2010). Mallin avulla saatoimme siis analysoida kertomuksista tapahtumien kulkua, mikä vastasi pyrkimystämme tarkastella työuupumusta prosessina. Tällöin erityisenä tarkastelun kohteena olivat kertojien merkittävinä pitämät tapahtumat tai tapahtumasarjat. Lisäksi malli avasi näkökulmia toimijoiden omiin arvostuksiin ja käsityksiin työuupumuksestaan. Pyrimme löytämään tekijöitä, joita uupumuksen kokeneet pitivät merkittävinä uupumuksen eri vaiheissa ja millaisia erilaisia selviytymiskeinoja heillä oli.

Mallissa (Labov ja Waletzky 1997) olevat kuusi kertomuksen rakenneosaa ovat seuraavat:

1. Abstrakti. Tiivistää kertomuksen aiheen ja vastaa kysymykseen mistä asiassa on kyse.

2. Orientaatio. Esittelee kertomuksen tapahtumien paikan, ajan ja tilanteen sekä henkilöt. Orientaatio vastaa kysymyksiin kuka, mitä, missä ja milloin.

3. Komplikaatio. Ilmaisee tapahtumien käänteet, niiden väliset ristiriidat ja kertoo mitä tapahtui. Se vastaa kysymykseen mitä sitten tapahtui. 
4. Resoluutio. Esittää tapahtumasarjan lopputuloksen ja vastaa kysymykseen mitä lopulta tapahtui.

5. Arviointi. Ilmaisee kertomuksen merkityksen sen kertojalle tai yleisemmin vastaamalla kysymykseen mikä on kertomuksen tarkoitus ja/tai miksi se kerrottiin.

6. Kooda. Sulkee ja palauttaa kertomuksen nykyhetkeen.

Nostimme mallin avulla jokaisesta kertomuksesta esiin sellaiset kerronnalliset elementit, jotka ilmaisevat jotakin oleellista työuupumuksesta ja siitä selviytymisestä. Analyysimme eteni seuraavin askelin. Ensin kukin haastattelu luettiin siten, että tavoitteena oli rakentaa haastateltavien kertomusten ajallinen rakenne. Tällöin hahmotettiin työuupumusta edeltävä, sen aikainen ja sen jälkeinen aika ja näin saatiin käsitys työuupumuksen prosessiluonteesta. Seuraavaksi rakennettiin aineistoon pohjautuva kertomusten tyypittely. Kertomustyyppejä muodostui yhteensä neljä. Kun ajallinen rakenne ja kertomusten tyypittely olivat valmiina, siirryttiin haastatteluita tarkastelemaan Labovin ja Waletzkyn (1997) mallin rakenneosien kautta.

\section{TYÖUUPUMUSKERTOMUSTYYPIT}

Aineistosta nousi esiin neljä työuupumusta käsittelevää kertomustyyppiä. Kertomustyypit olivat kiistäjäkertomus, sinnittelijäkertomus, selviytyjäkertomus ja puolustajakertomus. Seuraavaksi käydään läpi nämä kertomustyypit yksitellen ja tarkastellaan niiden kautta työuupumusprosessien eroja. Vaikka kunkin haastateltavan kertomukset olivatkin monin osin yksilöllisiä, oli niistä mahdollista luoda nämä neljä tyyppiä. Kukin tyyppi siis tiivistää työuupumuskertomusten keskeisiä piirteitä ja ominaisuuksia. Kertomustyyppien ja haasteltavien nimeäminen ei perustu vain yhteen tiettyyn kriteeriin ja nimeämisen peruste vaihtelee tapauskohtaisesti. Näin siksi, että halusimme nimetä tyypit ja haastateltavat siten, että ne kuvaavat kyseisiä kertomuksia ja kertojia parhaiten. Nimeämisen peruste vaihtelee siten haastatellun/haastateltujen omasta kielenkäytöstä johonkin kyseistä tyyppiä keskeisesti edustavaan termiin. Tästä syystä nimeämisessä käytetyt termit eivät ole yksiselitteisiä, vaan niille voi löytää muitakin vaihtoehtoja. Esitämme kunkin kertomustyypin kohdalla yhden mallikertomuksen, jonka prosessiluonnetta avataan tarkastelemalla sitä Labovin ja Waletzkyn (1997) kertomuksellisen mallin kautta.

\section{Kiistäjäkertomukset}

Haastateltavista kolme kuului kiistäjiin. Kuten tyypin nimikin sanoo, heidän käsityksensä oli, ettei varsinaista työuupumusta vakavana masennustilana ole olemassa. Myöskään uupumuksen ja työn yhteyttä ei tunnusteta. On olemassa vain tavanomaista väsymystä tai lievää uupumusta, mutta ei työuupumuksen vakavinta ilmenemismuotoa. He myös palauttivat työuupumuksen yksilötason ongelmaksi siten, että se on yksilön itsensä korjattavissa ja hoidettavissa.

Kiistäjäkertomusten esimerkiksi olemme valinneet Myllertäjäksi nimetyn haastateltavan kertomuksen. Nimi Myllertäjä tulee hänen omasta lausahduksestaan, jossa hän kuvaa työasioitaan ajoittaiseksi myllerrykseksi. Myllertäjän kerronnasta voidaan myös tunnistaa individualistisen sankarin piirteitä, mikä kertoo nimeämisen monitulkintaisuudesta. Labovin ja Waletzkyn mallin ensimmäinen osa, abstrakti, tiivistää mistä kertomuksessa on kyse. Myllertäjän kertomuksessa keskeisessä roolissa ovat työn imu ja työaikojen venyminen. Työn imuun liittyy ajan kulumisen huomioimista heikentävä voimakas työhön uppoutuminen, mikä sitten johtaa työpäivien venymiseen (ks. Schauffeli ym. 2002; Hakanen 2005; Hyvönen ym. 2009). Myllertäjä on myös edennyt urallaan yhä haastavampiin johtamistehtäviin.

\footnotetext{
"Työpäivä venähtää ja kello on puoli seitsemän illalla. Innostun ja tajuan, että mulla muuten nälkä paljonkohan kello on. [...] Yhtäkkiä mennyt se päivä silleen, että en ole tajunnut, että on mennyt ja sitten tekstiä kyllä tulee ja tämmöistä suoritetta, mutta se imu voi olla hirveen kova."
}

Mallin toinen osa, orientaatio, selventää kertomuksen aikaa, paikkaa, kontekstia ja henkilöitä. Johtuen haastateltujen henkilöllisyyden salaamisesta, orientaatio-osassa ei voi kovin paljoa antaa tietoa. Voidaan todeta, että Myllertäjän kohdalla hänen omat esimiehensä ovat antaneet tukea ja esimiesten toiminta yleisesti voi olla 
uupumuskierteen katkaisevaa tai positiiviseen suuntaan ohjaavaa. Lisäksi Myllertäjä painottaa työpaikan ulkopuolisten tekijöiden merkitystä uupumuksen synnyssä. Esimerkiksi kodin ja muun yksityiselämän tapahtumat, kuten avioero tai läheisten sairastumiset, kriisiyttävät elämää ja se näkyy sitten myös työpaikoilla.

Myllertäjän kertomuksen komplikaatio eli tapahtumien käänteet ilmenevät jännitteisinä siten, että hän on kokenut itse väsymystä ja stressiä työssään, mutta toisaalta hänen kova työnimunsa on toiminut niiden vastavoimana. Tästä seuraa, että hän ei osaa itse määritellä tilanteensa laatua tai vakavuutta.

"Viime keväänä ensimmäistä kertaa alkoi tuntua, että mää en tunne itseäni enää aktiiviseksi. Varmaan se oli jossain määrin pakkotahtinen tekeminen ja semmoinen ilottomuus, ärsytyskynnys ja suunnaton väsymys."

"En ole ihan varma, että olenko kokenut vai enkö kokenut viime keväänä sitä [työuupumusta]."

Keskeinen taitekohta Myllertäjällä oli silloin, kun työpaineet lisääntyivät ja ne alkoivat ylittää työnimun tasoittavan voiman. Hän alkoi tunnistaa uupumuksen oireita itsessään huomatessaan olevansa iloton, helposti ärsyyntyvä ja väsynyt. Työuupumuksen hän kuitenkin kiistää vetoamalla omaa hyvään stressinsietokykyynsä ja uupumuksen syyn siirtäminen työasioiden ulkopuolisiin tekijöihin.

”Työstähän pitää väsyä ja vaikka me ei tehdäkään mitään ojankaivuuta. Tuntuisi erikoiselta, jos työviikon jälkeen en tuntisi väsymystä."

"Luulen, että työ ei minua yksissään uuvuta, että siihen täytyisi tapahtua jotain niin kun siinä siviilielämässä.”

Ratkaisuna eli Labovin ja Waletzkyn (1997) mallin resoluutiona Myllertäjä pohtii mahdollisuutta jäädä lomalle, kuitenkin nimenomaan vuosilomalle, ei sairauslomalle. Tällainen tilanteen määritys sopii hänen käsitykseensä työuupumuksesta: hän ei edelleenkään myönnä työuupumuksen työperäisyyttä, vaan katsoo sen johtuvan työn ulkopuolisista tekijöistä.
"Silloin minun pitää vaikka jäädä lomalle, vuosilomalle."

"Syytetään sitä työtä [...] Kyllähän työnantajat joutuvat varmasti korvaamaan semmoisiakin järjestelyjä, jotka tapahtuvat ihmisen yksilön oman käytöksen kautta tulleesta tai sitten sen mitä hänen lähipiirissään on tapahtunut."

Mallin viimeiset osat, arviointi ja kooda, voidaan käsitellä samassa yhteydessä, koska kertomuksen merkitys kertojalleen ja sen umpeen kurominen ovat niin läheisiä toisilleen. Oman uupumuksensa arvioinnissa nousee esiin edelleenkin työperäisen työuupumuksen kiistäminen ja sen näkeminen yksilötason ongelmana. Tästä seuraa, että ainoastaan ihminen itse voi ratkaista ongelmansa ja toipua työuupumuksesta. Työnantajalla ei ole paljoakaan mahdollisuuksia siihen vaikuttaa. Myllertäjä sijoittuu sikäli harmaalle alueelle, että hän tunnistaa kyllä joitakin oireita, mutta ei tunnusta itsensä varsinaisesti kokeneen työuupumusta. Tällainen tilanne kertoo työuupumuksen yksiselitteisen diagnosoimisen vaikeudesta. Oman elämänsä ratkaisun Myllertäjä teki siirtymällä vuorotteluvapaalle ja sitten myöhemmin toisen kuntatyönantajan palvelukseen.

\section{Sinnittelijäkertomukset}

Sinnittelijäkertomuksia oli aineistossa eniten, mikä kielii siitä, että sinnittely on tyypillinen reaktio työuupumukseen. Sinnittely voidaan ymmärtää myös työuupumusta vastaan kamppailun yleisemmäksikin vaiheeksi. Rikala (2013) on määritellyt sinnittelyn työn vaatimusten ja yksilön pystymisen pitkittyneeksi ristiriidaksi, jossa yleensä yksilön ulkopuoliset syyt muunnetaan hänen omiksi heikkouksikseen. Siten myös tässä tutkimuksessa tämän tyypin kertomuksille on tyypillistä, että työuupumus salataan eikä siitä haluta työyhteisössä puhua. Kaikkiaan seitsemän haastateltavan kertomukset luokiteltiin sinnittelykertomuksiksi. Sinnittelijöitä näistä haastateltavista tuli sen vuoksi, että he tunnistivat itsensä sairaiksi, mutta eivät halunneet jäädä sairauslomalle hoitamaan työuupumustaan. Heillä kenelläkään ei ollut missään vaiheessa lääkärin toteamaa työuupumusdiagnoosia eikä siten myöskään lääkärin määräämää sairaus- 
lomaa. Rikalan (2013) tutkimuksessa tuli esiin, että lääkäriin menoa pitkitettiin, mutta lopulta se oli piste, jossa työuupumuksesta tuli oikea ja hyväksyttävä vaiva.

Sinnittelijöistä esimerkkinä toimii Oravanpyöräksi nimetyn henkilön kertomus. Oravanpyöräksi nimeäminen perustui hänen työuupumuksensa etenemiseen kasvavien suorituspaineiden kautta ja sen muuttumiseen peloksi tulla työpaikalle. Hänen tapauksessaan tulee esiin myös työelämän vaatimusten kiristyminen yksilötasolla koettuina. Kertomuksen yhdistetyssä abstraktissa ja orientaatiossa Oravanpyörä on valmistunut yliopistosta ja saanut vähitellen johtotehtäviä kunnallisella kentällä. Työn vastuullisuus ja kuormittavuus ovat myös kasvaneet uralle etenemisen myötä ja työpäivät alkaneet venyä. Hän on myös vastuuntuntoinen, jopa ylitunnollinen, mikä johtaa kokemukseen siitä, että hänen tunnollisuuttaan käytetään hyväksi. Hän ei kykene sanomaan omalle esimiehelleen ei ja kokee jäävänsä työasioiden kanssa yksin.

"Hölmö, että toi tekee. Laitetaan tekemään, antaa sen tehdä [...] Tein yli kolme vuotta, että mää istuin illat täällä. Se on työuupumus sitä, että aamulla heräät ja ensimmäinen ajatus on, että päivä pelottaa."

Kertomuksen komplikaatio ei ole mikään yksittäinen hetki tai tapahtuma vaan pienet vähittäiset tapahtumat, jotka johtavat työuupumukseen. Oravanpyörän kertomus on tyypillinen esimerkki asteittaisesta työuupumuksen kehittymisestä tunnollisella johtajalla. Aholaym.(2010) mukaan motivoitunut ja korkeat tavoitteet itsellensä asettanut johtaja kuuluu työuupumuksen riskiryhmään. Oravanpyörän kertomuksessa työhön sitoutuneisuus ja kasaantuvat työtehtävät tuottavat jännitteen, josta seuraa työn mielekkyyden katoaminen koska työtehtävien hoitamiseen ja johtamistyöhön ei jää enää aikaa. Ongelmat oman esimiehensä kanssa ovat myös vaikeuttaneet hänen työtehtävistä suoriutumistaan. Esimies saattoi pyörtää jo tehtyjä päätöksiä ja suunnitelmia ja siten lisätä Oravanpyörän kuormitusta.

"Johtamiselle ei jää aikaa, että johtajilla on liian paljon suorittavaa työtä, ja burnout ja sairasloma on lähtenyt just siitä, että olet jäänyt niiden rutiinien alle ja et pysty ennakoi- maan. Et jaksa, et pysty, et jaksa suunnitella mitään vaan yrität jokaisen työpäivän elää, että mitä tänään kaatuu ja selvitä niistä."

"Yhdessä esimiehen kanssa linjattiin minkälaista mallia esitetään, niin kun tulevaisuuden organisoimiseksi. Kunnes tuli seuraava aamu ja tulin omalle työpaikalle ja menin oman esimiehen luokse, niin hän sanoi ... että ei hyväksy sitä minkä oli minun kanssani yhdessä valmistellut. [...] Olin tehnyt hirveen työn ihmisten kanssa ja [...] ja minun oma esimies oli tukemassa sitä, ja kunnanhallitus oli kerinnyt tekemään jo päätöksenkin siitä, että näin tehdään, niin siinä koin, että multa vedettiin täysin matto alta ja täysin väärin perustein."

Varsinaista kertomuksen loppuun kurovaa resoluutiota ei Oravanpyörän kertomuksessa ole. Hän jää sinnittelemään työuupumuksensa kanssa tunnistaen kyllä itsessään sen tunnusmerkit. Selviytymiskeinoina on sekä hänen motivoituneisuutensa että työuupumuksen salaaminen esittämällä ulospäin vahvaa ja rempseää.

"Kun minä näytän niin vahvalta ja kun minä olen naurava ja rempsee niin ehkä se [esimies] oikeastikaan tajua, että tässä mennään oikeasti suorituksen äärirajoilla.”

Arvioidessaan omaa työuupumustaan Oravanpyörä tunnistaa sen keskeiset piirteet itsessään: väsymyksen, kyynistymisen, ammatillisen itsetunnon heikkenemisen ja pelkotilat. Hän myös peittää oman työuupumuksensa iloiseen ilmiasuun koska kokee organisaatiossa vallitsevan eräänlaisen vaikenemisen kulttuurin. Työuupumuksesta ei johtotasolla puhuta eikä sitä käsitellä millään tavalla. Kollektiivista vaikenemista hän pitää erittäin ongelmallisena koska se vaikeuttaa työuupumuksen tunnistamista ja siitä toipumista. Näin hän pitää työuupumusta organisaatiotason ongelmana. Toisaalta hän kuitenkin uskoo, että johtamisella voidaan vaikuttaa työuupumuksen syntyyn organisaatioissa.

"Meillä on vaikenemisen kulttuuri. Johtoryhmän jäsen päällikkö oli pitkällä burnout lomalla, ei siitä ole tässä sen jälkeen keskusteltu, kun hän on takaisin tullut." 
"Voiko työuupumusta johtaa? Voiko johtaa organisaatiota niin, että ei tule työuupumusta? Minä uskon siihen, että voi johtaa, että ihmiset eivät uuvu."

Oravanpyörän kertomuksen koodassa ratkaisuksi nousee työpaikan vaihto. Oravanpyörä on pohtinut toisiin töihin hakeutumista koska kokee mahdollisuutensa vaikuttaa omaan työhönsä olemattomiksi ja siksi itsensä voimattomaksi. Työpaikan vaihtaminen on usein viimeinen ratkaisu tilanteessa, jossa työntekijä kokee, ettei enää jaksa (Maslach ja Leiter 1997). Tätä kirjoitettaessa Oravanpyörä on myös toteuttanut työpaikan vaihdon.

"Minä poistun tästä kunnasta kokonaan. Jos elämä menee vaikeaksi tehdä itselle loppuvuodesta ihan älytön sadan prosentin varma helvetti tai sitten antaa olla näin ja poistua paikalta jossakin vaiheessa."

\section{Selviytyjäkertomukset}

Selviytyjäkertomuksia oli aineistossa kaksi. Kumpikin oli kokenut työuupumuksen itse, kuten kertomustyyppikin ilmaisee. Sinnittelijäkertomusten tapaan selviytyjäkertomuksissa työuupumuksen olemassaolo ja vakavuus tunnustetaan ja sitä pidetään työperäisenä. Samoin työuupumuksen vaikutuksia hyvinvointiin ja fyysiseen terveyteen myönnetään. Siinä missä sinnittelijäkertomuksissa työuupunut henkilö pyrkii yksilönä salaamaan ongelmansa, selviytymiskertomuksissa työuupumus nähdään kollektiivisena, kaikkia johtoryhmien jäseniä koskevana ilmiönä. Selviytymiskertomuksia näistä tekee se, että työuupumuksen kokeneet eivät ole pelkästään selviytyneet siitä, vaan he näkivät työuupumuksensa positiivisena ja osin myös voimaannuttavana oppimisprosessina.

Selviytyjäkertomuksista käymme tässä tarkemmin läpi Uhrautujaksi nimetyn pitkän uran kunta-alalla tehneen haastateltavan kertomuksen. Uhrautujaksi hänet tekee se, että hän kokee huolehtivansa liikaa toistenkin tehtävistä ja tekemisistä, mutta ei niinkään itsestään ja omasta jaksamisestaan. Uhrautujan kertomuksen abstraktin ja orientaation keskeisinä piirteinä edellisen lisäksi on tunnollisuus ja suorittaminen, jotka hän sanoo tunnistaneesta itsestään jo lapsena. Perfektionismi on heijastunut hänen työurallaan pettymyksen kokemuksina, joita voi pitää hänen työuupumuksensa alkutekijöinä. Pettymyksiä on vahvistanut kokemus oman esimiehen tuen puutteesta.

"Täytyy sanoa, että välillä nousee pintaan semmoiset negatiiviset tunteet. Ja semmoinen olo tulee vähän niin kun, että kyllä varmaan huonosti käy. Kun tietää, että on ollut näitä pettymyksiä eri tilanteissa."

Uhrautujan kertomuksen komplikaation muodostaa uupumuksen kehittyminen työasioiden ja työn ulkopuolisten tekijöiden yhteisvaikutuksesta. Hänen kohdallaan tulee esiin myös työuupumuksen määrittelemisen vaikeus. Hän itse katsoo olleensa masentunut ja se on myös merkitty hänen sairauslomansa syyksi. Toisaalta hänen kertomuksessaan esiintyy työuupumuksenkin tunnusmerkit. Tämän tutkimuksen kannalta ei ole oleellista, kuinka lääketieteellisesti oikeellinen hänen diagnoosinsa on, vaan miten työn ja työn ulkopuolisen elämän yhteisvaikutus tuotti hänelle sairausloman arvoisen uupumuksen. Uhrautuja mainitsee työn lisäksi elämänsä ihmissuhdeasiat ja talouteensa liittyneet ongelmat.

"Virallinen nimi sairaslomassa onkin masennus. Ei siinä työuupumuksesta puhuta. [...] Koska, jos siellä puhutaan työuupumuksesta niin kyllähän siitä saa sen käsityksen, että se on nimenomaan pääosin ja ainoastaan työstä johtuva uupumus. Ja ei se mulla ainakaan niin ollut, se oli vain niin, kun osa kokonaisuutta."

"Mutta että kyllä aina välillä tuntuu siltä, että [...] sitä huolehtii ja ajattelee, että ei sitä pitäisi koko ajan. Mutta tuntuu, että murheet maailman asioistakin tullee niin kovana, että ahdistaa."

"Niin se väsymys ja kaikkia fyysisiä oireita, että rupesi tulemaan semmoinen olo, että tuntuu että kuolee tähän paikkaan."

Uhrautujan arviossa nousee esiin hänen tapansa huolehtia kaikista asioista sekä se, että hän tunnistaa tämän ominaisuuden ongelmaksi. Samoin 
hän pystyy tunnistamaan uupumusta aiheuttavia ulkoisia tekijöitä, kuten eristäytymisen työyhteisön arkisista kohtaamisista ja tapahtumista. Uupumusta aiheuttavien tekijöiden tunnistaminen oli kuitenkin hänelle tapa selvitä siitä. Keskeistä Uhrautujan selviytymiselle oli sairauslomien jälkeen eristäytymisen välttäminen ja pääsy takaisin työyhteisöön. Työuupumuksesta johtuneiden sairauslomien tuottama epävarmuus työyhteisön suhtautumisesta paluuseen ei siten ollut hänellä merkittävää. Hän pystyi keskustelemaan asiasta työyhteisössään ja siten työuupumus yleensäkin muuttui kollektiiviseksi asiaksi. Näin ollen tarinan kooda on paluu työyhteisöön tietoisena yhteisön positiivisesta merkityksestä työuupumuksesta selviytymiselle. Tällä hetkellä Uhrautuja ei ole enää työelämässä.

"Kiinnittää huomiota silloin, jos käy niin että tietyssä vaiheessa esimerkiksi minä en käynyt kahvilla."

"Kyllä se vastaanotto takaisin on tärkeätä. Musta on varmaan sekin, että siitä pystyy puhumaan työkavereiden kanssa, niin että se auttaa. Myös sen uupuneen on itsekin hyvä pystyä puhumaan siitä niiden kanssa. Ei se ainakaan, sillä että ei puhuta siitä mitään muuta, se ei ainakaan edistä asiaa.”

"Hyvä puoli uupumuksesta, kun sen kerran on ollut, että tavallaan ne hälytysmerkit ja muut. Niin sen se opetti, että niitä tavallaan tunnistaa."

"Välillä, että niin kun tuntuu ihan mukavalta [työssäkäynti]. Nauttii ja välillä on ihan helpottava olo."

\section{Puolustajakertomukset}

Puolustajakertomuksissa, joita oli aineistossa kaksi, työuupumusta ei kyseenalaisteta ja siitä johtuvaa sairauslomaa pidetään muista syistä johtuvien sairauslomien kaltaisena. Puolustajakertomuksissa kertoja ei välttämättä ole itse ollut työuupunut tai tunnista väsymystään työuupumukseksi. He asettuvat kuitenkin tukemaan työuupumuksen kokeneita ja osaavat eläytyä uupuneen asemaan. Avunantaminen uupuneille on myös näiden kertomusten keskeinen ele- mentti. Näissä kertomuksissa työuupumus nähdään myös organisaatiotason ongelmana.

Puolustajakertomuksissa tarkastelemme lähemmin Muutoksenhakijaksi nimetyn haastateltavan kertomusta. Hänen kertomuksensa abstraktiin kuuluu työ- ja asuinpaikan muutokset ja siirtyminen kunta-alalle näiden myötä. Näistä muutoksista on peräisin myös hänen pseudonyyminsa. Kunta-alalle siirtyminen on tarkoittanut hänelle myös henkilöstöjohtamisen opettelua. Muutoksenhakijan kertomuksessa ei ole varsinaista komplikaatiota ja resoluutiota eli tapahtumien käänteitä ja niiden ratkaisua johtuen siitä, että hän ei ole itse kokenut työuupumusta. Muutoksenhakijan kokemukset työuupumuksesta perustuvat siihen, että hän on joutunut seuraamaan tapauksia omassa työyhteisössään.

"Itsellä ei ole tämmöistä varsinaista työuupumusta eikä väsymystä ollenkaan. Jokainen voi tuntea joskus uupumusta."

Komplikaation ja resoluution sijaan Muutoksenhakijan kertomuksessa on runsaasti arviointia, jossa hän pohtii työuupumuksen vaikutuksia ja merkitystä työyhteisöön ja johtamiseen. Ensinnä, hän kiinnittää huomiota työuupumuksen kasautuviin vaikutuksiin muiden työtaakassa. Työuupunut ei välttämättä kykene suoriutumaan omista työtehtävistään tai hänen suoriutumisensa on heikkoa ja työskentely tehotonta, mikä lisää muiden työtaakkaa. Samalla ongelmaksi nousee myös työuupuneen oman osaamisen ja asiantuntemuksen poistuminen organisaatiosta.

"Työuupumus niin se on tietyllä tavalla kuin mikä tahansa sairaus. Yksi henkilö tietyllä työpanoksella poissa, niin se kaatuu muiden niskaan. Hänen osaamisensa on pois käytöstä ja joudutaan pärjäämään jäljellä olevien henkilöiden voimin."

"Henkilö ei tavallaan kykene pitämään sitä osaamistaan, asiantuntemustaan, hän väsyy tämän takia."

Toiseksi, Muutoksenhakija pohtii työyhteisön sosiaalisia suhteita työuupumustapauksessa. Hänen kokemuksensa mukaan työuupunut työntekijä ei välttämättä suhtaudu kanssatyönteki- 
jöihin entiseen tapaansa ja voi siten aiheuttaa ongelmia työyhteisön ihmissuhteissa. Hän myös laajentaa työuupumuksen koko yhteisön ja organisaation kriisiksi. Johtaminen on erityisen keskeisessä asemassa mitä tulee työyhteisön avoimuuteen ja yhteishenkeen. Kokemusten jakamisen tulisi olla helppoa, eikä siihen saisi liittyä häpeää. Siten hän näkee yhteisön myös voimavarana.

"...kun henkilö on uupunut ja miten hän reagoi ja miten hän suhtautuu muihin ihmisiin ja kaataako millä tavalla kuormaa muille noissa ongelmissa."

"Se ei ole pelkästään sen henkilön kriisi ja ongelma, vaan kyllä se on myös koko työyhteisön tämmöinen perustavaa laatua oleva kriisi. [...] Työyhteisö voi olla myös voimavara, joka auttaa selviytymään ja pääsemään takaisin raiteille kenties."

"Oman esimiehen käyttäytyminen on hirveen merkittävässä roolissa, että kyllä se johtaminen pitää olla ihmisiä tulevaa eikä tukahduttavaa. Ja että ihmiset kokevat sen, että heillä on niin kuin hyvä työskennellä siellä työpaikassa. Kyllä sillä on merkittävä vaikutus, että keskusteluyhteys toimii."

Muutoksenhakijan kertomuksen koodaksi voi tulkita sen, että hän on tätä kirjoitettaessa jatkanut muutoksen hakuaan ja siirtynyt toisen kunnan palvelukseen. Hänen mukanaolonsa tässä tutkimuksessa perustuu siihen, että tarkastelemme työuupumusta myös työyhteisöjen näkökulmasta. Vaikka Muutoksenhakija ei olekaan itse ollut työuupunut, hän on kokenut ilmiön yhteisön jäsenenä ja johtajana. Siten hän tuo esiin työuupumuksen sosiaalisia ja työyhteisöä koskevia seikkoja.

\section{JOHTOPÄÄTÖKSET}

Tämän tutkimuksen keskeisenä tehtävänä oli saada tietoa työuupumuksen erilaisista ilmenemismuodoista. Tutkimuksessa keskityttiin kunta-alalle ja siellä johtotehtävissä toimiviin henkilöihin. Käytännöllisenä tavoitteena oli ennen kaikkea tuoda esiin työuupumuksesta selviytymisen keinoja ja ratkaisumalleja yksilötasolla.
Työuupumuksen yhteiskunnallisiin konteksteihin tämä tutkimus ei yltänyt, koska ne vaativat laajemman tarkastelun ja tässä tutkimuksessa haluttiin kokeilla narratiivisen menetelmän soveltuvuutta työuupumuksen tutkimukseen.

Tutkimuksessa nousi esiin työuupumuksen kahtalaisuus. Toisaalta työuupumus on yksilöllinen ilmiö. Haastateltavat suhtautuivat työuupumukseen tapauskohtaisesti eritavoin ja sillä oli erilaisia ilmenemismuotoja riippuen sen kokijan konteksteista. Toisaalta työuupumuksen kokemuksissa oli yhtäläisyyksiä, joiden perusteella eri kertomustyypit voitiin muodostaa. Tämä kertoo siitä, että ihmisillä on kuitenkin myös kulttuurisesti määrittyneitä ja jaettuja tapoja merkityksellistää työuupumusta. Nämä jaetut tavat ymmärtää työuupumusta voivat olla oleellisia silloin, kun työuupumukseen ja siitä selviytymiseen halutaan vaikuttaa sekä itse että ulkopuolisesti. Näin siksi, että jaetun kokemuksen kautta voi sekä työuupunut että ulkopuolinen taho luoda yhteistä ymmärrystä tilanteesta ja löytää siihen ratkaisumalleja. Kukaan ei siten ole täysin yksin työuupumuksensa kanssa. Narratiivinen analyysimenetelmä mahdollisti työuupumuksen jaettujen kokemusten analyysin.

Aineiston analyysin kautta muodostuneissa neljässä kertomustyypissä tiivistyy työuupumukseen oleellisesti kiinnittyviä tekijöitä. Alla olevasta taulukosta ilmenee, miten eri kertomustyypeissä suhtaudutaan työuupumuksen työperäisyyteen, millainen asema työuupumukselle on annettu, kenellä on vastuu työuupumuksesta, miten siitä on selvitty sekä mikä merkitys työyhteisöllä on ollut. Työuupumuksen syntymisen kontekstilla tarkoitetaan sen työperäisyyttä eli onko kyse nimenomaan työtehtävien kuormittavuuden, huonon esimiestyön, työyhteisön ristiriitojen tms. tuottamasta työuupumuksesta, vai onko siinä vaikuttavina tekijöinä työn ulkopuoliset huolet ja vaikeudet. Statuksella viitataan kokijan, johdon ja työyhteisön suhtautumista työuupumuksen vakavuuteen, sekä miten sitä ilmennetään tai miten sitä voi tuoda näkyviin yhteisössä. Eroja löytyi myös siinä, kenen tai minkä instituution katsottiin olevan vastuussa työuupumuksesta selviytymisessä. Taulukkoon on erikseen merkitty vielä selviytymiskeinot sekä työ yhteisön merkitys työuupumustapauksessa.

Ainoastaan kiistäjäkertomuksissa työuupumuksen katsottiin olevan työpaikan ulkopuoli- 
Taulukko 1. Yhteenveto kertomuksista

\begin{tabular}{|c|c|l|l|l|l|l|}
\hline Kertomustyypit & Lkm & $\begin{array}{l}\text { Synnyn } \\
\text { konteksti }\end{array}$ & $\begin{array}{l}\text { Millainen } \\
\text { status }\end{array}$ & $\begin{array}{l}\text { Kenen } \\
\text { vastuu }\end{array}$ & $\begin{array}{l}\text { Selviytymis- } \\
\text { keino }\end{array}$ & $\begin{array}{l}\text { Työyhteisön } \\
\text { merkitys }\end{array}$ \\
\hline $\begin{array}{l}\text { Kiistäjä- } \\
\text { kertomukset }\end{array}$ & 3 & $\begin{array}{l}\text { Ei } \\
\text { työperäinen }\end{array}$ & $\begin{array}{l}\text { Ei todellinen, } \\
\text { kuitataan } \\
\text { väsymykseksi }\end{array}$ & $\begin{array}{l}\text { Yksilö } \\
\text { itse }\end{array}$ & $\begin{array}{l}\text { Ei keinoa, } \\
\text { koska ei todellinen } \\
\text { sairaus }\end{array}$ & $\begin{array}{l}\text { Yksilön } \\
\text { ongelma, } \\
\text { ei merkitystä }\end{array}$ \\
\hline $\begin{array}{l}\text { Sinnittelijä- } \\
\text { kertomukset }\end{array}$ & 7 & Työperäinen & $\begin{array}{l}\text { Todellinen, } \\
\text { mutta salattu }\end{array}$ & $\begin{array}{l}\text { Yksilö } \\
\text { itse }\end{array}$ & $\begin{array}{l}\text { Työpaikan vaihto, } \\
\text { uupumuksen } \\
\text { kätkeminen }\end{array}$ & $\begin{array}{l}\text { Hämärä, } \\
\text { koska ei yhtei- } \\
\text { sössä tiedetty }\end{array}$ \\
\hline $\begin{array}{l}\text { Selviytyjä- } \\
\text { kertomukset }\end{array}$ & 2 & Työperäinen & $\begin{array}{l}\text { Todellinen, } \\
\text { jaettu }\end{array}$ & $\begin{array}{l}\text { Työ- } \\
\text { yhtei- } \\
\text { sö }\end{array}$ & $\begin{array}{l}\text { Avoimuus ja } \\
\text { paluu työ- } \\
\text { yhteisöön }\end{array}$ & $\begin{array}{l}\text { Vahva, koska } \\
\text { yhteisöllisesti } \\
\text { jaettu, } \\
\text { voimaannuttava }\end{array}$ \\
\hline $\begin{array}{l}\text { Puolustaja- } \\
\text { kertomukset }\end{array}$ & 2 & Työperäinen & $\begin{array}{l}\text { Todellinen, } \\
\text { ei itse } \\
\text { koettu }\end{array}$ & $\begin{array}{l}\text { Työ- } \\
\text { yhtei- } \\
\text { sö }\end{array}$ & $\begin{array}{l}\text { Työyhteisön ja } \\
\text { johdon aktiivinen } \\
\text { toiminta }\end{array}$ & $\begin{array}{l}\text { Avunanto, } \\
\text { tukeminen }\end{array}$ \\
\hline
\end{tabular}

nen ilmiö. Tämän voi ymmärtää johtuneen pitkälti siitä, että näissä kertomuksissa työuupumusta ei katsottu olevan olemassakaan. Sitä pidettiin lähinnä jonkin muotoisena väsymyksenä, mutta ei vakavana sairautena. Muissa kolmessa kertomustyypissä työuupumusta pidettiin työperäisenä. Kiistäjäkertomuksia lukuun ottamatta työuupumusta pidettiin myös todellisena ilmiönä, mutta näiden kolmenkin tyypin välillä ilmeni eroja. Kiistäjäkertomusten ja puolustajakertomusten välillä on kiinnostava epäsuhta. Kun kiistäjäkertomuksissa itse työuupumusta ei pidetty todellisena, vaikka haastateltavat olivatkin tunteneet sen oireita, niin puolustajakertomuksissa kertojilla ei itsellä ollut oireita, mutta he pitivät työuupumusta todellisena. Tällä epäsuhdalla oli merkitystä, kun tarkastellaan selviytymiskeinoja ja työyhteisön merkitystä työuupumustapauksissa. Ensinnä, kiistäjäkertomuksissa vastuu työuupumuksesta sälytettiin selkeästi yksilölle itselleen, kun puolustajakertomuksissa se oli vahvasti työyhteisöllä. Toiseksi, kiistäjillä ei ollut selviytymiskeinoa eikä työyhteisöllä merkitystä työuupumuksen käsittelyssä, koska he eivät tunnustaneet sen olemassaoloa. Puolustajat taas näkivät johtamistavoilla ja yhteisöllä olevan merkittävä positiivinen vaikutus työuupumuksen käsittelyssä ja siitä paranemisessa. Näissä kohdin kiistäjäkertomukset ja puolustajakertomukset ovat keskenään hyvin vastakkaiset.
Näitä kahta yllämainittua tyyppiä kiinnostavampana voidaan pitää sinnittelijäkertomusten ja selviytyjäkertomusten välistä eroa suhteessa työuupumuksen statukseen, siitä selviytymiseen ja työyhteisöön. Ensin mainitut salasivat työuupumuksensa tavalla tai toisella, kun jälkimmäiset taas toivat sen avoimesti yhteisön tietoon ja käsiteltäväksi. Tästä seurasi, että sinnittelijöillä vastuu työuupumuksesta sälytettiin uupujalle itselleen eikä siitä selviytymiskeinoja oikeastaan ollut. Myös kaikki työyhteisön tuen hyödyt jäivät heiltä saamatta, koska yhteisölle ei kerrottu työuupumuksesta. Sinnittelijät eivät olleet myöskään varsinaisesti toipuneet työuupumuksestaan, vaan se jäi heille pitkäaikaisemmaksi vaivaksi. Selviytyjät sen sijaan toivat työuupumuksensa työyhteisön tietoon ja jaettavaksi, mikä osoittautui myös heidän selviytymiskeinokseen. Työuupumuksen avoin käsittely työyhteisössä mahdollisti heille kunniallisen paluun yhteisöön ja oli siten myös voimaannuttava kokemus. He myös kaikista tutkituista olivat parantuneet työuupumuksestaan parhaiten.

Jos työuupumusta ja siitä selviytymistä tarkastellaan kokonaisuutena, tulee työyhteisön merkitys esiin vahvana positiivisena voimavarana. Näissä tutkituissa kertomuksissa parhaiten olivat selviytyneet ne ihmiset, jotka olivat voineet jakaa kokemuksensa työkavereiden ja esimiestensä kanssa. Työuupumuksen tunnus- 
taminen todelliseksi sairaudeksi on ensimmäinen askel, joka ohjaa löytämään keinoja sen voittamiseen. Tällöin työuupumus voidaan tehdä yhteisöllisesti hyväksytyksi ongelmaksi, eikä se jää yksilön omaksi häpeäksi ja huoleksi. Tällaisessa yhteisöllisessä ja kokonaisvaltaisella työuupumuksen käsittelyllä on hyvät mahdollisuudet muovata siitä voimaannuttava kokemus ei pelkästään sairastuneelle itselleen, vaan myös koko työyhteisölle. Johtamisella ja esimiestyöllä on myös suuri vaikutus siihen, miten työuupumusta organisaatioissa käsitellään ja hoidetaan.

Tutkimuksemme rajoituksina voidaan mainita, että emme voineet tässä tekstissä tarkastella työuupumusta sukupuolen tai iän näkökulmasta. Myös aiheen sitominen yhteiskunnallisiin rakenteisiin ja toimijuuteen ei ollut mahdollista käytettävissä olevan tilan rajallisuuden vuoksi. Jouduimme pitäytymään pilottityyppisessä tutkimuksessa, jossa työuupumusta tarkastellaan nimenomaan narratiivisella tutkimusmenetelmällä. Yllämainitut teemat ovat luonnollisesti tärkeitä jatkotutkimuksen aiheita. Lisäksi olisi kiinnostavaa laajentaa aineistoa siten, että kertomus- ja kertojatyyppien rakentaminen syvenisi ja sitä kautta saisimme lisätietoa työuupumuksesta ilmiönä.

\section{LÄHTEET}

Ahola, K. 2007. Occupational Burnout and Health. People and Work Research Reports 81. Helsingin yliopisto. Helsinki: Työterveyslaitos.

Ahola, K., Virtanen, M., Pirkkola, S \& Suvisaari, J. 2010. Työ ja mielenterveys. (Toim.) Aromaa, A. \& Koskinen, S. Suomalaisten työ, työkyky ja terveys 2000-luvun alkaessa. Raportti 11/2010. Terveyden ja hyvinvoinninlaitos.

Boje, D. 2008. Storytelling Organizations. London: Sage Publications.

Bruner, J. S. 1986. Actual Minds, Possible Worlds. Cambridge, Ma.: Harvard University Press.

Frantsi, P. 2013. Johtajuutta etsimässä. Naislähijohtajan identiteettitarinan rakentuminen siivoustoimialalla. Jyväskylä Studies in Business and Economics 129. Jyväskylän yliopisto.

Freudenberger, H. J. 1974. Staff burnout. Journal of Social Issuses. 30, (159-165).

Golembiewski, R, T \& Münzenrider R, F. 1988. Phases of Burnout. Developments in Concepts and Applications. New York: Praeger.

Hakanen, J. 2005. Työuupumuksesta työn imuun: työhyvinvointitutkimuksen ytimessä ja reunaalueilla. Työ ja ihminen Tutkimusraportti 27. Helsinki: Työterveyslaitos.

Hakanen, J \& Perhoniemi, R. 2012. Työn imun ja työuupumuksen kehityskulut ja tarttuminen työtoverista toiseen. Helsinki: Työterveyslaitos.

Hyvärinen, M. 2006. Kerronnallinen tutkimus. [online]. Saatavilla www-muodossa: http://www.hyvarinen.info/material/ Hyvarinen- Kerronnallinen_tutkimus.pdf

Hyvärinen, M. 2010. Haastattelukertomuksen analyysi. Teoksessa Ruusuvuori, J., Nikander, P. \& Hyvärinen, M. (toim.): Haastattelun analyysi. Tampere. Vastapaino.
Hyvönen, K., Feldt, T., Salmela-Aro, K., Kinnunen, U., \& Mäkikangas, A. 2009. Young managers'drive to thrive: A personal work goal approach to burnout and work engagement. Journal of Vocational Behavior, 75(2), 184 (183-196). Saatavilla www-muodossa. https://doi.org/10.1016/j.jvb.2009.04.002

Kalimo, R \& Toppinen, S. 1997. Työuupumus Suomen työikäisellä väestöllä. Helsinki: Työterveyslaitos.

Kinnunen, U \& Hätinen, M. 2005. Työuupumus ja jaksaminen työelämässä. Teoksessa: Työ leipälajina. Työhyvinvoinnin psykologiset perusteet. Toim. Kinnunen, U., Feldt, T \& Mauno, S. Jyväskylä: PS-kustannus, (38-55).

Labov, W \& Waletzky, J. 1997 [1967] Narrative Analysis: Oral Versions of Personal Experience. Journal of Narrative and Life History (7), (3-38).

Leiter, M. P \& Maslach, C. 1988. The impact of interpersonal environment of burnout and organizational commitment. Journal of Organizational Behavior (9), (297-308).

Maslach, C. 1976. Burned-out. Human Behavior. 5 (9), 16-22.

Maslach, C. 1982. Burnout - the cost of caring. New York: Prentice-Hall.

Maslach, C \& Leiter, M. P. 1997. The truth about burnout. How organizations cause personal stress and what to do about it. San Francisco: Jossey-Bass Publishers.

Maslach, C., Schaufeli, W. B \& Leiter, M. P. 2001. Job burnout. Annual Review of Psychology. 52, (397-422). Saatavilla www-muodossa: http://www.wilmarschaufeli.nl/publications/ Schaufeli/154.pdf 
Otala, L \& Ahonen, G. 2003. Työhyvinvointi tuloksen tekijänä. Helsinki. WSOY.

Polkinghorne, D. E. 1995. Narrative configuration in qualitative analysis. Teoksessa J.A. Hatch \& R. Wisniewski (toim.): Life History and Narrative. London: Falmer Press, (5-23).

Rikala, S. 2013. Työssä uupuvat naiset ja masennus. Acta Universitatis Tamperensis 1854. Tampere: Tampere University Press.

Schaufeli, W \& Enzmann, D. 1998. The burnout companion to study \& practive: A critical analysis. London: Taylor \& Francis.

Schaufeli, W.B., Salanova, M., González-Romá, V \& Bakker, A, B. 2002. The measurement of engagement and burnout: A two sample confirmatory factor analytic approach. The Journal of Happiness Studies. 3, (71-92).

Schaufeli, W.B \& Bakker, A.B. 2004. Jod demands, job resources, and their relationship with burnout and engagement: A multi-sample study. Journal of Organizational Behavior, 25, (293315).
Sintonen, T. 1999. Etninen identiteetti ja narratiivisuus. Kanadan suomalaiset miehet elämänsä kertojina. Jyväskylä: SoPhi.

Tarkkonen, J. 2012. Työhyvinvointi johtamistehtävänä. Periaatteet, rakenteet ja käytännöt. Helsinki: Unipress.

Vartiovaara, I. 1987. Burnout henkinen pahoinvointi. Juva: WSOY.

Vartiovaara, I. 1996. Burnoutista jaksamiseen - Aika itkeä, aika iloita. Helsinki: Otava.

Widerberg, K. 2006. Embodying Modern Times: Investigating tiredness. Time and Society. Volume: 15 issue: 1, page(s): 105-120.

Viitala, R. \& Lehto, K. 2014. Kovat ajat kuntien henkilöstöjohtamisessa. Teoksessa Henkilöstöjohtaminen uuden edessä. Henkilöstöbarometrin nostamat kehityshaasteet. Viitala. R ja Järlström, M. (toim.). Vaasan yliopiston julkaisuja. Tutkimuksia 302. Vaasa: Vaasan yliopisto. 